\title{
Mathematical Programming for Business and Industry
}




\section{Studies in Management}

General Editor: SAMUEL EILON, D.SC (ENG.), PH.D, D.I.C, M.I.MECH.E, M.I.PROD.E Professor of Industrial and Management Engineering, Imperial College, London

Network Analysis

for Planning and Scheduling

Exercises in Industrial Management A Series of Case Studies

Applied Queueing Theory
Albert Battersby

S. Eilon, R. I. Hall and J. R. King

A. M. Lee 


\section{Mathematical Programming for Business and Industry}

K. Brian Haley, B.Sc., Ph.D.

Senior Lecturer in Operational Research, University of Birmingham

MACMILLAN EDUCATION 


\author{
MACMILLAN AND COMPANY LIMITED \\ Little Essex Street London, WC2 \\ also Bombay Calcutta Madras Melbourne \\ THE MACMILLAN COMPANY OF CANADA LIMITED \\ 70 Bond Street Toronto 2 \\ ST MARTIN'S PRESS INC \\ I75 Fifth Avenue New York NY IooIo
}

Additional material to this book can be downloaded from http://extra.springer.com.

(C) K. B. HALEY I967

Softcover reprint of the hardcover 1st edition 1967

First published 1967

$9 \times 6,168$ pages

73 line illustrations

ISBN 978-1-349-00113-2 ISBN 978-1-349-00111-8 (eBook)

DOI 10.1007/978-1-349-00111-8 


\section{Preface}

The various methods of linear programming described in this book assume a knowledge of school mathematics but are developed from typical industrial problems. I have attempted to use examples to show how practical complications can be introduced into the standard routines. Some of the cases that are described were chosen from less well known fields of application.

The principle adopted has been to avoid complicated mathematical proofs but at the same time to illustrate the mathematical results. The references have been arranged into three categories namely direct references to papers, theoretical references to four standard texts, and a set of references to practical applications in various fields. In this way I hope that readers who are interested in the mathematics will find it easy to develop their interest while at the same time non-mathematical readers will not be put off by involved formulae.

Birmingham,

K. BRian Haley

September I966 
To Diana 


\title{
Contents
}

\author{
Preface v \\ I Linear Programming Problems I \\ 2 The Simplex Method II \\ 3 The Transportation Problem 26 \\ 4 Practical Applications of Transportation Model 42 \\ 5 Transhipment Applications $\quad 56$ \\ 6 Distribution Problems 80 \\ 7 Generalised Problems 87 \\ 8 Integer Programming 99 \\ 9 Simplex Applications Ir9 \\ Io Mathematical Programming $\quad$ I35 \\ References $\quad \mathrm{I}_{42}$ \\ Bibliography $\quad \mathrm{I} 44$ \\ Exercises $\quad \mathrm{I} 47$ \\ Index $\quad$ I55
}


Throughout this book most references will be given by a number. The exceptions occur to the practical methods. Four standard reference books are called $I, I I, I I I, I V$ and wherever possible the techniques are referred to in these by quoting the book followed by a page number. For example (Dantzig $I, p .54$ ).

For further material relevant to this chapter the reader is referred to the early chapters of the books by Dantzig (I), Gass (II), Hadley (III) and Vajda (IV). 